\title{
Mycovellosiella robbsii SP. NOV. CAUSING LEAF-SPOT ON Mimosa caesalpiniaefolia
}

\author{
ROBERT W. BARRETO ${ }^{1}$ \& FILLIPE S. MARINI ${ }^{1}$
}

Departamento de Fitopatologia, Universidade Federal de Viçosa, 36571-000, Viçosa, MG, fax: (31) 3899-2240, e-mail: rbarreto@ mail.ufv.br

(Accepted for publication on 20/08/2002)

Corresponding author: Robert W. Barreto

BARRETO, R.W. \& MARINI, F.S. Mycovellosiella robbsii sp. nov. causing leaf-spot on Mimosa caesalpiniaefolia. Fitopatologia Brasileira 27:605-608. 2002.

\begin{abstract}
This is a description of the new species Mycovellosiella robsii, a cercosporoidal hyphomycete, associated with leaf spots on Mimosa caesalpiniaefolia, an important hedge plant with multiple uses in Brazil. The new species was compared to other cercosporoid species associated with plants of the genus Mimosa and other species of the genus Mycovellosiella described on legumes, and is recognized

as a distinct taxon. Koch's postulates were carried out and the disease was reproduced by inoculating healthy plants with mycelial suspension or disk, confirming the pathogenicity. This is the first report of a fungal disease on this host.

Additional key words: cercosporoid fungi, sabiá, sansão do campo, caatinga.

\section{RESUMO}

\section{Mycovellosiella robbsii sp. nov. causando manchas foliares em Mimosa caesalpiniaefolia}

Mycovellosiella robsii, uma nova espécie de fungo hifomiceto cercosporóide, é descrita em associação com manchas foliares em Mimosa caesalpiniaefolia, o sabiá ou sansão do campo (uma espécie de grande importância utilizada na formação de cercas vivas e para muitos outros usos no Brasil). Esta nova espécie foi comparada a outras espécies de hifomicetos cercosporóides associadas a plantas do gênero Mimosa e outras espécies

de Mycovellosiella descritas em leguminosas e reconhecida como um taxon distinto. Foram seguidos os passos dos postulados de Koch e reproduziu-se a doença após a inoculação de suspensão micelial e deposição de discos de culturas de $M$. robbsii sobre folhas de plantas sadias, comprovando-se a patogenicidade do fungo. Esta é a primeira doença fúngica a ser descrita neste hospedeiro.
\end{abstract}

\section{INTRODUCTION}

Mimosa caesalpiniaefolia Benth. (popular names sabiá or sansão-do-campo) is a spiny shrub or small tree that occurs naturally in the dry scrublands (caatinga) of Northeastern Brazil extending from the State of Maranhão to the State of Bahia (Lorenzi, 1992). It is a source of wood with many different uses, and used as fodder during the dry season. Because of its rustic nature, spiny stems and ornamental value, it has become one of the most important hedge plants in Brazil. There are no published records of fungal diseases on this plant species but C. F. Robbs (personal communication) noted that a leaf-spot, commonly found on this host in the State of Rio de Janeiro, was associated with a "Cercosporella-like fungus". Recently, the disease was observed at two different sites in the State of Minas Gerais (municipalities of Ponte Nova and Viçosa). This article reports on the identity of the causal fungus and its pathological status.

\section{MATERIAL AND METHODS}

Fresh samples of diseased M. caesalpiniaefolia were collected and brought to the lab at the Plant Pathology
Department at Federal University of Viçosa on different occasions. Some of these specimens were dried in a plant press and deposited in the Herbarium VIC. Conidia were collected from sporulating colonies with a sterilized fine-tip needle and transferred to Petri plates containing V8 juiceagar. Koch's postulates were fulfilled by inoculating several 20 -cm high plants using two techniques. Either mycelial disks from active colonies growing on V8 juice-agar were deposited on the adaxial surface of the leaves at different developmental stages or a mycelial suspension was brushed on both sides of the leaves. After inoculation the plants were kept in a moist chamber for $48 \mathrm{~h}$ and then transferred to a greenhouse bench. The plants were examined daily for the appearance of symptoms.

\section{RESULTS AND DISCUSSION}

\section{Taxonomy}

Mycovellosiella robbsii R.W. Barreto \& F.S. Marini sp. nov. (Figures 1 and 2 A-C)

Etymol: named after Charles F. Robbs eminent Brazilian plant pathologist and the first to observe this fungus. Maculae in foliis vivis, 2-19 $\mathrm{mm}$ latae, irregulares ad 


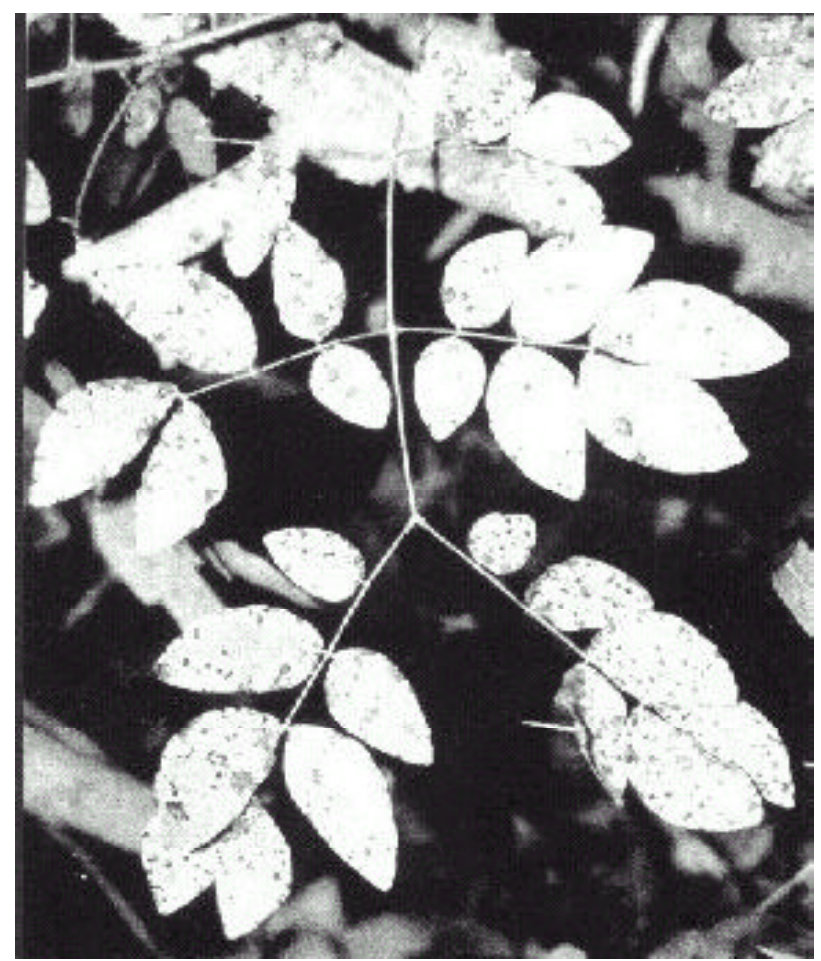

FIG. 1 - Mimosa caesapiniaefolia leaves showing symptoms of attack by Mycovellosiella robbsii.

subcircularis, brunneae cum margine nigris, coalescentes. Mycelium immersum septatum, ramosum, pallido brunneum. Mycelium superficiale amphiginae, sparsus, ad stromata exoriens, 2,0-6,5 $\mu \mathrm{m}$ diam, perparce ramosum, septatus, pallido brunnea ad subhyalinea, laevis. Stromata absentia ad praesentia, subrotundatis, 20.5-43.0 x 21.5-56.0 $\mu \mathrm{m}$. Conidiophora anphigenae, vel a) fasciculata, ad stromata exoriens, cilindracea, recta, flexuosa vel curvata, 17.0-39.0 x 3.0-4.0 $\mu \mathrm{m}, 1-5$ septatis, brunnea, laevis; vel b) sejunctum, ad mycelium superficiale exoriens, cilindracea, 12.5-31.5 x 3-5 $\mu \mathrm{m}, 0-3$ septatis, pallido brunnea, laevis. Conidia catenata (catenae ramosa et non ramosa), holoblasticae, cilindrica ad filiformis, recta vel leniter curvata, $15.0-124.5 \times 2.0-3.5 \mu \mathrm{mm}$, 1-11 septatis, hilum incrassati et fuscati, pallido brunnea, laevis.

Holotypus: VIC 22186, ex M. caesalpiniaefolia, Ponte Nova, MG, Brasilia, 20-10-2001, R.W. Barreto.

Paratypus: VIC 22183, ex M. caesalpiniaefolia, campus Universidade Federal de Viçosa, Viçosa, MG, Brasilia, 9-3-2001, R.W. Barreto; VIC 22185, ex M. caesalpiniaefolia, Bonsucesso, Viçosa, MG, Brasilia, 9-3-2001, R.W. Barreto; VIC 22184, ex M. caesalpiniaefolia, campus Universidade Federal de Viçosa, Viçosa, MG, Brasilia, 6-2-2001, R.W. Barreto; VIC 22217, ex M. caesalpiniaefolia, Rio Claro, RJ, Brasília, 15-3-2002, R.W. Barreto.

Lesions on living leaves, 2-19 mm wide, irregular and vein delimited to subcircular, brown with a black periphery, usually surrounded by water-soaked tissue, coalescing and leading to necrosis of an extensive leaf area and finally leaf fall. Internal mycelium branched, septate, brown. External mycelium amphiginous (but more abundant abaxially), sparse, not forming ropes or climbing on trichomes, originating from stromata $2.0-6.5 \mu \mathrm{m}$ diam, sparingly branched, septate, pale brown to subhyaline, smooth. Stromata usually present, erumpent, subsphaerical, compact but less dense or even hollowed or at least with less melanized yellowish central cells, 20.5-43.0 x 21.5-56.0 $\mu \mathrm{m}$, composed of brown textura angularis. Conidiophores anfiginous, of two kinds: a) fasciculate, originating from stomata or bursting through the cuticle, cylindrical, straight to slightly curved or flexuose, very rarely branched, 17.0-39.0 x 3.0-4.0 $\mu \mathrm{m}, 1-5$ septate, brown, smooth; b) isolate, originating from the external mycelium, cylindrical, mostly straight, unbranched, 12.5-31.5 x 3-5 $\mu \mathrm{m}, 0-3$ septate, pale brown, smooth. Conidiogenous cells terminal, integrated, polyblastic, holoblastic, proliferating simpodially, subcylindrical, pale brown. Conidiogenous loci conspicuous, $1-5$ per cell, $1 \mu \mathrm{m}$, thickened, darkened. Conidia dry, either isolate or forming acropetal branched or unbranched chains, holoblastic, cylindrical to filiform, mostly straight to slightly curved, occasionally slightly constricted in the middle, 15.0-124.5 x 2.0-3.5 $\mu \mathrm{m}$, apex subacute to rounded or subtruncate, base subtruncate, 1-11 septate, 1-3 cicatrized, scars thickened and darkened, eggutulate, subhyaline to pale brown, smooth.

In culture: Slow-growing (up to $24 \mathrm{~mm}$ diam in 19 days); raised centre of cottony white aerial mycelium overlaying a compact pseudostromatic portion composed of brown monilioid cells, in parts faintly tainted with a violet pigment (becoming strongly pigmented to violet when damaged with a tool), periphery flat and gray; reverse black centrally gradually becoming gray and finally white towards the periphery; no sporulation.

Holotype: VIC 22186, ex M. caesalpiniaefolia, Ponte Nova, MG, Brazil, $20^{\text {th }}$ Oct 2001, R.W. Barreto.

Paratype: VIC 22183, ex M. caesalpiniaefolia, campus Universidade Federal de Viçosa, Viçosa, MG, Brazil, $9^{\text {th }}$ Mar 2001, R.W. Barreto; VIC 22185, ex $M$. caesalpiniaefolia Bonsucesso, Viçosa, MG, Brazil, $9^{\text {th }}$ Mar 2001, R.W. Barreto; VIC 22184, ex M. caesalpiniaefolia, campus Universidade Federal de Viçosa, MG, Brazil, $6^{\text {th }}$ Feb 2001, R.W. Barreto; VIC 22217, ex M. caesalpiniaefolia, Rio Claro, RJ, Brazil, 15-3-2002, R.W. Barreto.

Four cercosporoid fungi have been described on Mimosa spp. but none on M. caesalpiniaefolia. These are: Cercospora hypsophila Sydow, Cercospora sensitivae (Speg.) Chupp (Chupp, 1954), Pseudocercospora mimosae (Pat.) U. Braun and Passalora mimosae (F. Stevens \& Dalbey) U. Braun (Braun, 1995). M. robbsii differs from all those species by having a combination of characteristics common to cercosporoids placed in the genus Mycovellosiella, particularly the presence of external mycelium, conidia in 

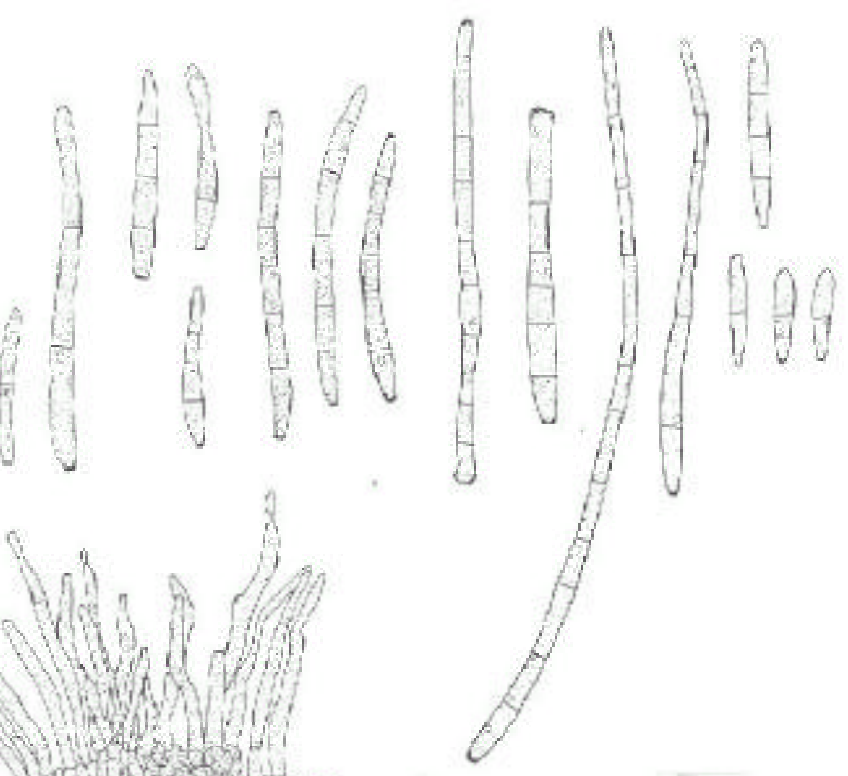

B

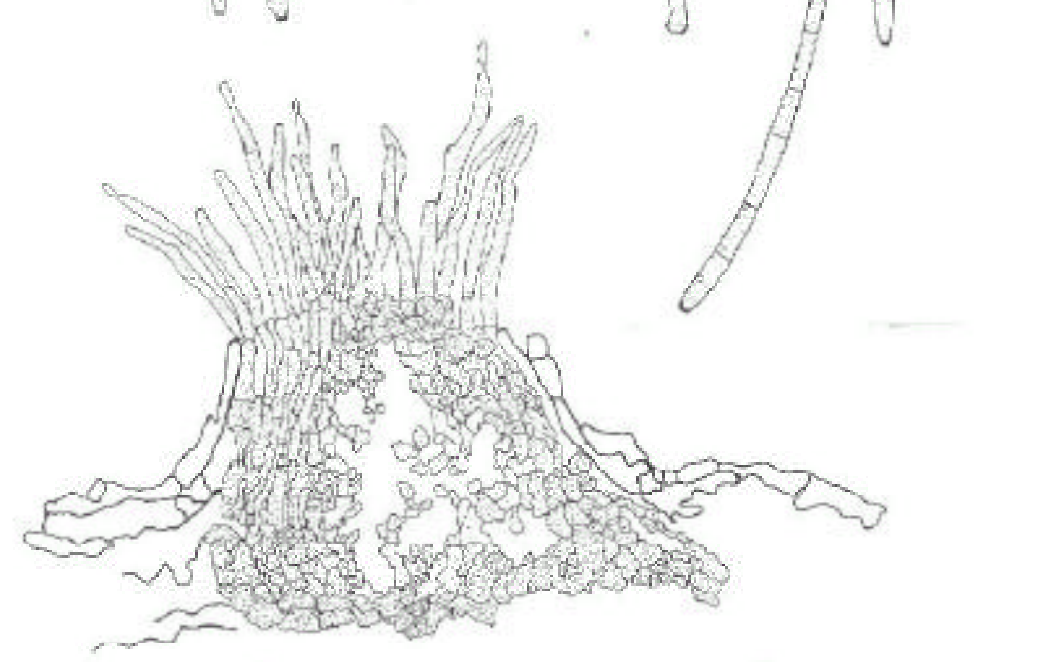

$\mathrm{C}$

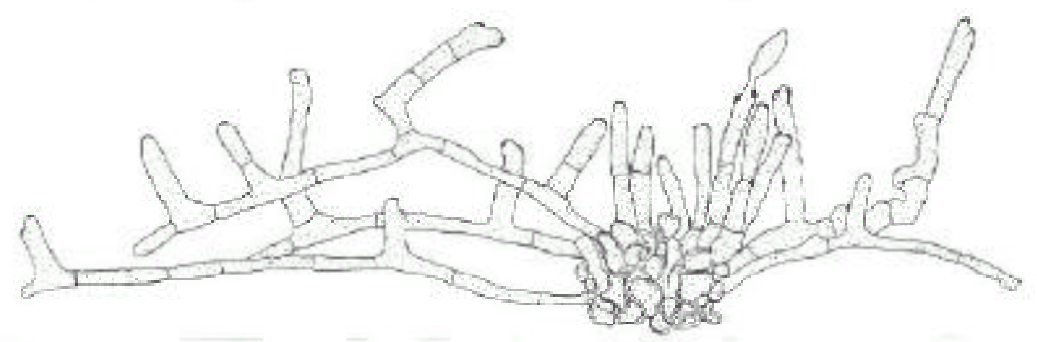

FIG. 2 - Mycovellosiella robsii: A - conidia; B - fascicle of conidiophores; C - external mycelium arising from a stroma with a fascicle of conidiophores. $(B a r=20 \mu \mathrm{m})$.

chains, darkened and thickened scars on conidia and conidiophores. Gutiérrez's (2000) monograph on cercosporoids from the Brazilian "cerrado" included a review on this group of fungi on the Leguminosae, adding several new taxa to the list of Brazilian cercosporoids including two potential new Mycovellosiella spp. on legumes. According to Gutiérrez (2000), besides his two new species, the following species of Mycovellosiella were found on members of the Leguminosae in the literature: Mycovellosiella atylosiae M.K. Bhalla \& S.K. Singh, M. atylosii R. Ram \& Mallaiah, M. bauhinia (Ellis \& Everh.) U. Braun, M. cajani (P. Henn.) Rangel ex Troter, $M$. greciana (Syd.) L.G. Brown \& Morgan-Jones, $M$. hariotii (Speg.) Deighton, M. litsiae Meenu, R.K. Bhalla \& S.K. Singh, M. malloti Kharwar, P.N. Singh \& R.K. Chaudhary, M. mucunae Kharwar, P.N. Singh \& R.K. Chaudhary, M. pirozynskii Deighton, M. pithecelobi (Mulder) Deighton, M. pumila (Syd. \& P. Syd.) U. Braun and M. roseae
(Winter) U. Braun. Mycovellosiella rosea was inaccurately included on this list, as Braun (1995) admitted to the erroneous combination and inclusion of this taxa in the genus Mycovellosiella and then supported the original view that this species belongs to genus Cercosporella. Mycovellosiella passaloroides (G. Winter) J.K. Bai \& M.Y. Cheng was also omitted from this list. The only species of Mycovellosiella on leguminous hosts that are described as having stromata are: Mycovellosiella cajani (P. Henn.) Rangel ex Trotter, M. hariotii, M. mucunae and M. passaloroides. M. robbsii differs from $M$. cajani by having narrower conidia that have a larger number of septa [4-6 ìm diam, 1-3 septated conidia in M. cajani Ellis (1971)] and conidiophores, which are very rarely branched as opposed to much branched in $M$. cajani. It differs from $M$. hariotii by having well developed stromata and catenulate conidia which are narrower than those of $M$. hariotii, which has poorly developed stromata and non- 


\section{R.W. Barreto \& F.S. Marini}

catenulate 5-6.5 ìm wide conidia (Kharwar et al 1996). Mycovellosiella mucunae has smaller stromata (10.5-16.0 ìm diam.) than those of $M$. robbsii and only forms unbranched chains of conidia (Kharwar et al. 1996). Mycovellosiella passaloroides has shorter and narrower conidia (up to 70 ìm long 3.5-5 ìm wide) which are only up to three septates (Bai \& Cheng, 1992). The new species described by Gutiérrez (2000) on Acosmium subelegans (Mohlenb.) Yakovl, besides being from a different host genus has no stromata, nor compact conidiophore fascicles and has shorter and wider conidia. The other species described by Gutiérrez (2000) on Chamaecrista orbiculata (Benth.) I. \& B. is closer to $M$. robsii, but has branched conidiophores and conidial scars not clearly thickened and darkened as in the species on the genus Mimosa and was described from a different host. This fungus deserves therefore to be recognized as a new species.

\section{Pathology}

Inoculated plants started showing disease symptoms eight days after inoculation and symptom development was slow. Initially a faint chlorotic area appeared on inoculated leaves. After 19 days necrotic lesions were widespread on inoculated leaves, particularly on those inoculated with mycelial suspension. No such symptoms appeared on uninoculated plants maintained as control. Sporulation of the fungus was observed on necrotic tissue of the leaf-spots. Infected leaves dropped subsequently. Isolation from such lesions yielded colonies identical to those described above.
Although relatively slow-developing under the conditions that predominated during this test, the disease was observed causing considerable damage to the foliage of $M$. caesalpiniaefolia in the field, particularly at the end of the tropical rainy season.

\section{LITERATURE CITED}

BAI, J.K. \& CHENG, M.Y. Some new combinations of the genus Cercosporidiumm Mycovellosiella, Pseudocercospora in China. Acta Mycologica Sinica 11:120-124. 1992.

BRAUN, U. A Monograph of Cercosporella, Ramularia and Allied Genera (Phytopahtogenic Hyphomycetes). Vol 1. IHW- Verlag: Eching bei München. 1995.

CHUPP, C. A Monograph of the Fungus Genus Cercospora. Ithaca. Published by the author. 1954.

ELLIS, M.B. Dematiaceous Hyphomycetes.. Kew. Commonwealth Mycological Institute. 1971.

GUTIÉRREZ, A.H. Fungos Cercosporóides em Plantas Nativas do Cerrado. (Doctoral Thesis). Brasília. Universidade Federal de Brasília. 2000.

KHARWAR, R.N., SINGH, P.N. \& CHAUDHARY, R.K. New species of Mycovellosiella associated with foliar spots in Nepal. Mycological Research 100:689-692. 1996.

LENNÉ, J.M. A world list of fungal diseases of tropical pasture species. Phytopahtological Papers 31: 1-162. 1990.

LORENZI, H. Árvores Brasileiras. Nova Odessa. Ed. Plantarum. 1992.

MEHROTRA, M.D. \& VERMA, R.K. Some new hyphomycetes associated with leaf spots of trees in India. Mycological Research 95:1163-1168. 1991. 